AN EVALUATION OF THE ROUND COMPACT SPECIMEN

FOR FATIGUE-CRACK GROWTH RATE TESTING

L. A. James and W. J. Mills

\title{
Apri1 1979
}

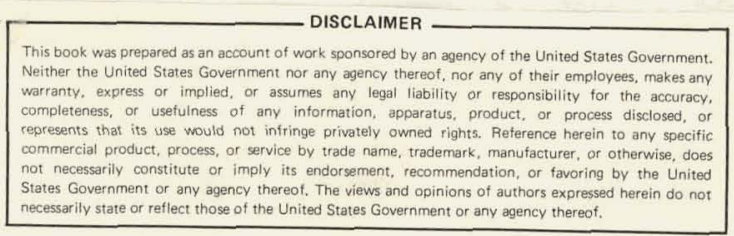

ASTM Symposium on Fatigue Crack Growth Measurement and Data Analysis

October 29-November 2, 1979

Pittsburgh, Pennsylvania

HANFORD ENGINEERING DEVELOPMENT LABORATORY

Operated by Westinghouse Hanford Company, a subsidiary of Westinghouse Electric Corporation, under the Department of

Energy Contract No. EY-76-C-14-2170 


\section{DISCLAIMER}

This report was prepared as an account of work sponsored by an agency of the United States Government. Neither the United States Government nor any agency Thereof, nor any of their employees, makes any warranty, express or implied, or assumes any legal liability or responsibility for the accuracy, completeness, or usefulness of any information, apparatus, product, or process disclosed, or represents that its use would not infringe privately owned rights. Reference herein to any specific commercial product, process, or service by trade name, trademark, manufacturer, or otherwise does not necessarily constitute or imply its endorsement, recommendation, or favoring by the United States Government or any agency thereof. The views and opinions of authors expressed herein do not necessarily state or reflect those of the United States Government or any agency thereof. 


\section{DISCLAIMER}

Portions of this document may be illegible in electronic image products. Images are produced from the best available original document. 
AN EVALUATION OF THE ROUND COMPACT SPECIMEN

FOR FATIGUE-CRACK GROWTH RATE TESTING

L. A. James and W. J. Mills

\section{ABSTRACT}

A proposed round compact specimen was evaluated for its suitability for fatigue-crack growth rate testing. The results were compared to results from standard compact specimens (per ASTM E647-78T), and the two specimens were found to yield equivalent results. A number of K-solutions have also been proposed for the round compact specimens, and these are reviewed. The agreement between the various solutions was quite good, and the Newman Equation was used to evaluate the present results. 


\section{AN EVALUATION OF THE ROUND COMPACT SPECIMEN}

FOR FATIGUE-CRACK GROWTH RATE TESTING

\section{INTRODUCTION}

Fatigue-crack growth tests commonly utilize the ASTM Compact Specimen which has been standardized in ASTM E647-78T. This specimen offers many desirable features: it has a well-characterized K-solution, offers a wide range of $\mathrm{K}$-levels within a single specimen at a given load, is conservative of material, has a relatively high compliance, and requires relatively low loads to achieve a given $\mathrm{K}-l$ level. However, perhaps the biggest disadvantage of the standard Compact Specimen (CS) is its relatively high cost. Since fracture mechanics tests are sometimes required on materials with a circular cross-section (e.g., round bar stock, sintered products, etc.), a round version of the Compact Specimen would have attractive cost-saving features, and indeed several such specimens have been proposed and utilized. (1-6) ASTM Committee E-24 (Fracture Testing of Metals) is currently considering round Compact Specimens for standardization. Because most of the previous studies have been aimed at fracture toughness testing applications, the present study was undertaken to evaluate the Round Compact Specimen (RCS) design for fatiguecrack growth rate testing.

\section{STRESS INTENSITY FACTOR SOLUTIONS}

A requirement for any specimen design to be considered as a laboratory standard is an accurate K-solution over a wide range of crack lengths. A number of K-solutions for RCS designs have been proposed $(1,2,6,7,9,10)$, and they will be briefly reviewed and compared herein.

Feddern and Macherauch, ${ }^{(1)}$ conducted compliance tests on Round Compact Specimens (see Figure 1 and the appendix for definitions) and derived the relationship given in Equation [1]. This relationship was proposed for the range $0.3<a<0.7$.

$$
K=\frac{P \sqrt{a}}{B W}\left[29.6-162 \alpha+492.6 \alpha^{2}-663.4 \alpha^{3}+405.6 \alpha^{4}\right]^{2}
$$

Mowbray and Andrews ${ }^{(2)}$ conducted compliance tests as well as two analytical procedures (finfte element and J-integral) to derive K-solutions. The 
expressions from the three methods all gave similar results, but they considered the finite element results to be the most accurate. Their relationships for $K$ and load-line displacement are given in Equations [2] and [3], respectively, for the range $0.475<\alpha<0.825$.

$$
\begin{aligned}
& K=\frac{P}{B \sqrt{W}} \exp \left[-8.51+56.67 \alpha-112.01 \alpha^{2}+98.18 \alpha^{3}-28.47 \alpha^{4}\right] \\
& \delta=\frac{P}{E B} \exp \left[11.77-65.63 \alpha+175.61 \alpha^{2}-194.99 \alpha^{3}+82.94 \alpha^{4}\right]
\end{aligned}
$$

Gross, ${ }^{(6)}$ using a boundary collocation technique, derived the relationship of Equation [4], where

$$
K=\Gamma\left(\sigma_{p}+\sigma_{m}\right) \sqrt{A_{t}\left(\overline{\left.T-A_{t} / R_{0}\right)}\right.}
$$

$\Gamma, \sigma_{p}, \sigma_{m}, A_{t}$, and $R_{0}$ are defined in Ref. 6 . Equation [4] is valid over the range $0.533<\alpha<0.80$. In a later paper, ${ }^{(7)}$ Gross extended his collocation solution for $K$ to cover the range $0.133<\alpha<1.0$. Crack surface displacements have also been determined by Gross ${ }^{(8)}$ over the range $0.2<\alpha<0.933$.

Cull and Starrett ${ }^{(4)}$ conducted compliance experiments on an RCS and, al though they did not derive values of $K$ from these compliances, their plots of $2 \mathrm{BEC}$ versus $\mathrm{a} / \mathrm{W}$ can be used to derive $K$ using the expressions of Equation [5] for the range $0.3<\alpha<0.6$.

$$
\left.\begin{array}{rl}
\frac{d(2 B E C)}{d(a / W)} & =2 B E W\left[\frac{d C}{d a}\right] \\
G & =\frac{p^{2}}{2 B} \frac{\partial C}{\partial a} \\
K & =\sqrt{G E}
\end{array}\right\}
$$

Underwood and Kendal1 ${ }^{(9)}$ have developed a C-shaped specimen for fracture mechanics testing. Although it differs from the RCS shown in Figure 1 , in the 1 imit the $C$-Specimen approaches the RCS as the inner radius shrinks to zero. Therefore, the equation for the $C$-Specimen can be used to estimate $K$ in the RCS over the relatively narrow range $0.633<\alpha<0.7$, if the inner radius is taken to be zero.

Gregory, ${ }^{(10)}$ using an asymptotic analys is, developed the expression of Equation [6], valid over the range $0.5<\alpha<0.8$, where $b=W-a$. 


$$
K=\frac{P}{B \sqrt{W}}\left[\frac{2}{\left(\frac{D}{W}\right)\left(\frac{D}{W}-\frac{b}{W}\right)}\right]^{1 / 2}\left[\frac{\frac{D}{W}-\frac{b}{W}}{0.3557\left(\frac{b}{W}\right)^{1.5}}+\frac{2-\frac{D}{W}}{0.9665\left(\frac{b}{W}\right)^{0.5}}\right]
$$

Finally, Dr. James C. Newman, Jr. of the NASA Langley Research Center has used boundary collocation methods to derive an expression for the stress intensity factor of the RCS that is valid over a wide range of $\alpha: 0.25 \leq \alpha<1.0$. This relationship, given in Equation [7], is considered the most accurate over this wide range of $\alpha$, and is the equation used to calculate the present results. Equation [7] is likely the one to be adopted by ASTM Committee E-24.

$$
K=\frac{P}{B \sqrt{W}}\left[\frac{2+\alpha}{(1-\alpha)^{1.5}}\right]\left[0.76+4.8 \alpha-11.58 \alpha^{2}+.11 .43 \alpha^{3}-4.08 \alpha^{4}\right]
$$

It is interesting to compare the various relationships for $K$, but in order to do so they must be expressed in a common manner. * A convenient way of comparing the results is through the use of a non-dimensional geometry factor, $Y$, defined in Equation [8]. Values of $Y$ for the various

$$
K=\frac{P}{B \sqrt{W}} Y \text {. }
$$

K-solutions are plotted in Figure 2 as a function of $\alpha$, and it is seen that in general the agreement is quite good. Also plotted is the solution ${ }^{16)}$ for the standard Compact Specimen as given by Equation [9]. It will be noted in Figure 2 that Equations [7] and [9] give reasonably similar results, and the higher values of $Y$ associated with the RCS at large values of $\alpha$ are undoubtedly related to the removal of the material in the corners of the specimen. Figure 2 also shows that a larger range of $Y$ (and hence $K$ ) is possible for an RCS than for a standard CS with the same width $W$. Hence, at least in theory, it may be possible to get slightly more fatigue-crack growth rate data from an RCS.

$$
K=\frac{P}{B \sqrt{W}}\left[\frac{2+\alpha}{(1-\alpha) 1.5}\right]\left[0.886+4.64 \alpha-13.32 \alpha^{2}+11.72 \alpha^{3}-5.6 \alpha^{4}\right]
$$

\section{EXPERIMENTAL PROCEDURE}

The material used to evaluate the RCS in this study was Alloy 718 , a precipitation-hardenable nickel-base alloy. The chemical composition of this material is given in Table II. All specimens (with the exception of Specimen

*The geometries utilized by the various investigators are summarized in Table 1 . 
1907) were obtained from a piece of $76.2 \mathrm{~mm}$ (3 in.) diameter bar stock. Specimen 1907 was machined from a $50.8 \mathrm{~mm}$ ( 2 in.) diameter bar from a different heat of material. Following machining, the specimens were given a precipitation heat treatment consisting of:

Solution anneal 1 hour at $1093^{\circ} \mathrm{C}\left(2000^{\circ} \mathrm{F}\right)$, cool to $718^{\circ} \mathrm{C}\left(1325^{\circ} \mathrm{F}\right)$ at $56^{\circ} \mathrm{C} /$ hour $\left(100^{\circ} \mathrm{F} /\right.$ hour $)$, age 4 hours at $718^{\circ} \mathrm{C}\left(1325^{\circ} \mathrm{F}\right)$, cool to $621^{\circ} \mathrm{C}$ $\left(1150^{\circ} \mathrm{F}\right)$ at $56^{\circ} \mathrm{C} /$ hour $\left(100^{\circ} \mathrm{F} /\right.$ hour $)$, age 16 hours at $727^{\circ} \mathrm{C}\left(1150^{\circ} \mathrm{F}\right)$, . air cool.

Tensile tests were not performed on this material, but the average room temperature hardness in the heat-treated condition was $R_{c}=41.7$. The results of tensile tests on another heat of Alloy 718 given the same heat-treatment (resulting in $R_{C}=41.4$ ) may be found in Ref. 11 .

Two types of specimens were employed in this study: standard Compact Specimens (per ASTM E647-78T) with nominal width and thickness dimensions of $38.1 \mathrm{~mm}(1.50 \mathrm{in.})$ and $8.89 \mathrm{~mm}$ ( $0.35 \mathrm{in.})$, respectively, and round compact Specimens with nominal width, diameter and thickness dimensions of $51.2 \mathrm{~mm}$ (2.25 in.), $76.2 \mathrm{~mm}$ (3.00 in.) and $8.89 \mathrm{~mm}$ (0.35 in.), respectively. Specimen 1907 had $W$ and $B$ dimensions of $37.6 \mathrm{~mm}$ ( $1.48 \mathrm{in.})$ and $7.62 \mathrm{~mm}$ (0.30 in.), respectively. All specimens were in the C-R orientation per ASTM E399-78.

The specimens were fatigue cycled on a feedback-controlled electrohydraulic testing machine using load as the control parameter. Tests were conducted in an air environment at room temperature and at $538^{\circ} \mathrm{C}\left(1000^{\circ} \mathrm{F}\right)$. Sinusoidal waveforms were employed at frequencies of $600 \mathrm{cpm}$ and $40 \mathrm{cpm}$. for the tests at room temperature and $538^{\circ} \mathrm{C}$, respectively. The stress ratio $\left(R=\mathrm{K}_{\min } / \mathrm{K}_{\max }\right)$ was 0.05 for all tests. The test parameters are summarized in Table III.

Crack lengths were determined periodically throughout each test using a traveling microscope. Fatigue-crack growth rates (da/dN) were calculated using the "secant method", (12) and the corresponding stress intensity factors (K) were calculated using Equations [7] or [9], as appropriate. The results were displayed as plots of $\log (d a / d N)$ versus $\log (\Delta K)$, where $\Delta K$ is the stress intensity factor range $\left(K_{\max }-K_{\min }\right)$.

A few of the data points were "not valid" according to the recently adopted ASTM method for fatigue-crack growth rate testing, E647-78T. These data were plotted as closed symbols. At low values of $\Delta K$, a few data points were obtained for crack extensions less than $2.5 \mathrm{~mm}(0.10 \mathrm{in}$.) from the 
machined notch. At high values of $\Delta K$, a few data points violated the criterion for remaining uncracked ligament size:

$$
(w-a) \geq \frac{4}{\pi}\left(\frac{K_{\max }}{\sigma_{y}}\right)^{2}
$$

where $\sigma_{y}$ is the $0.2 \%$ offset monotonic yield strength.* Although these data easily satisfied a less restrictive criterion based on flow strength rather than yield strength, (13) they are nevertheless displayed herein as "invalid".

\section{RESULTS AND DISCUSSION}

The results of the crack growth tests conducted at room temperature and $538^{\circ} \mathrm{C}\left(1000^{\circ} \mathrm{F}\right)$ are shown in Figures 3 and 4 , respectively. At both test temperatures the two specimen designs appear to give equivalent results. The two Round Compact Specimens tested at each temperature had test loads differing by $50 \%$, thereby producing the same value of $K$ with different combinations of load and crack length. Again, agreement between the two specimens is excellent. Ref. 12 established that a scatter factor of 2 is considered normal for intralaboratory tests on a single heat, and the present results fall within that general guideline. The slightly greater scatter at $538^{\circ} \mathrm{C}\left(1000^{\circ} \mathrm{F}\right)$ is attributed to the greater difficulty in measuring the crack lengths at elevated temperatures.

To further evaluate the equivalency of the results, least-squares regression analyses were performed on the data for each specimen design at both temperatures. The results (expressed in American Customary. Units) are given below (Individual regression lines are not plotted in Figures 3 and 4):

Standard C.S. at $24^{\circ} \mathrm{C}$ (Specimens $1516 \& 1517$ )

$\log (\mathrm{da} / \mathrm{dN})=-20.441+3.3159 \cdot \log (\Delta \mathrm{K})$

Correlation Coefficient** $=0.9895$

Round C.S. at $24^{\circ} \mathrm{C}$ (Specimens $1519 \& 1520$ )

$\log (\mathrm{da} / \mathrm{d} N)=-20.246+3.2674 \cdot \log \left(\Delta K_{\mathrm{K}}\right)$

Correlation Coefficient $=0.9913$

Standard C.S. at $538^{\circ} \mathrm{C}$ (Specimen 1518)

$\log (\mathrm{da} / \mathrm{dN})=-17.181+2.6829 \cdot \log (\Delta K)$

Correlation Coefficient $=0.9626$

*Values of $\sigma_{y}=1011 \mathrm{MPa}(146.7 \mathrm{ksi})$ and $866 \mathrm{MPa}(125.6 \mathrm{ksi})$ at 24 and $538^{\circ} \mathrm{C}$, respectively, were obtained 'from Ref. 11.

$\star \star A$ correlation coefficient of unity indicates a perfect fit. 
Round C.S. at $538^{\circ} \mathrm{C}$ (Specimens 1521 \& 1522)

$\log (\mathrm{da} / \mathrm{dN})=-17.023+2.6505 \cdot \log (\Delta \mathrm{K})$

Correlation Coefficient $=0.9750$

Only those data considered valid by ASTM E647-78T (i.e., the open symbols in Figures 3 and 4 ) were included in the regression analyses. It is seen that the regression equations for the two specimen designs are very similar. In fact, comparison of these equations at the extreme growth rates where data for the two designs overlap indicates a maximum difference in da/dN between the two equations at room temperature of $9.9 \%$, and at $538^{\circ} \mathrm{C}\left(1000^{\circ} \mathrm{F}\right)$ a maximum difference of $4.6 \%$. Again, this is considered well within normal scatter and indicates the equivalency of the results.

It is interesting to note that, even though the "invalid" data were not included in the regression analyses, examination of Figures 3 and 4 suggests that they continued to exhibit behavior comparable to that of the valid data.

Although there are minor differences in the quantities $L / W, D / W, d / W$, and $r / W$ between the specimen analyzed by Newman and those used in the present work and previous studies (see Table I), the excellent agreement between the various K-solutions (see Figure 2) as well as the good agreement in the present study between standard and round specimens suggests that these minor dimensional variations are relatively unimportant.

Finally, the regression lines for other heats of similarly heat-treated Alloy 718 tested under identical conditions of temperature, frequency, waveform, and stress ratio (using Standard Compact Specimens.) are shown in Figures 3 and 4 for comparison purposes. It will be seen that the agreement between the present results and those of the previous studies is quite good, again suggesting the equivalency of the RCS.

\section{SUMMARY AND CONCLUSIONS}

The various K-solutions suggested for the RCS were reviewed, and found to be in good agreement with one another. The Newman Equation (Equation [/]) is considered the most accurate over the widest range of values of $\alpha$, and hence is the expression with which the present results are evaluated.

Although a large number of specimens were not tested, the results of this study suggest that the standard Compact Specimens and the Round Compact Specimen yield equivalent results for room temperature and elevated temperature 
fatigue-crack growth rate testing. Hence, considering the economic advantage of the RCS for some product forms, it appears to be a satisfactory alternative to the standard CS in these instances.

\section{ACKNOWLEDGEMENTS}

This work was performed by Westinghouse Hanford Company, a subsidiary of Westinghouse Electric Corporation, under U. S. Department of Energy Contract EY-76-C-14-2170. The authors wish to acknowledge the assistance of D. J. Criswell in conducting the tests.

\section{REFERENCES}

1. V. G. Feddern and E. Macherauch, "Eine neue Probenform für bruchmechanische Experimente," Zeitschrift für Metallkunde, Vol. 63, No. 12, pp. 882-884, 1973.

2. D. F. Mowbray and W. R. Andrews, "Stress Intensity Factor Calibration for a Compact Specimen with a Round Profile," Technical Information Series, General Electric Company, Schenectady, NY, January 1975.

3. N. Ingelstrom and V. Ustimenko, "The Influence of Porosity and Carbon Content on the Fracture Toughness of Some Sintered Steels, " Power Metallurgy, Vol. 18, No. 36, pp. 303-322, 1975.

4. A. D. Cull and H. S. Starrett, "A Study of Fracture Mechanics for Graphitic Materials," Report AFML-TR-75-125, Air Force Materials Laboratory, October 1975.

5. W. A. Van Der Sluys, H. S. Palme and P. K. Nair, "Specimen Selection for Reactor Vessel Surveillance Program, "Proceedings of Conference on Environmental Degradation of Engineering Materials, pp. 687-699, Virginia Polytechnic Institute and State University, BTacksburg, 1977.

6. B. Gross, "Mode I Stress Intensity Factors for Round Compact Specimens," Journal of Testing and Evaluation, Vol. 5, No. 6, pp. 457-460, 1977.

7. B. Gross, "Mode I Analys is of a Cracked Circular Disk Subject to a Couple and Force," Developments in Theoretical and Applied Mechanics, Vol. 9, R. M. Hackett (Ed.), pp. 195-203, P7enum Press, New York, 1978.

8. B. Gross, "Mode I Crack Surface Displacements for a Round Compact Specimen Subject to a Couple and Force," Technical Memorandum 79096, NASA Lewis Research Center, Cleveland, May 1979.

9. J. H. Underwood and D. P. Kendall, "K Results and Comparison for a Proposed Standard C-Specimen, "Report WVT-TR-74041, Watervliet Arsenal, Septcmber 1974. 
10. R. D. Gregory, "The Edge-Cracked Circular Disk Under Symmetric Pin-Loading," Technical Report No. 78-36, The University of British Columbia, Vancouver, October 1978.

11. L. A. James, "Fatigue-Crack Propagation Behavior of Inconel 718," Report HEDL-TME 75-80, Westinghouse Hanford Company, September 1975.

12. W. G. Clark and S. J. Hudak, "Variability in Fatigue Crack Growth Rate Testing," Journal of Testing and Evaluation, Vol. 3, No. 6, pp. 454-476, 1975.

13. L. A. James, "Specimen Size Considerations in Fatigue-Crack Growth Rate Testing," Report HEDL-TME 78-99, Westinghouse Hanford Company, December 1978.

14. L. A. James, "Heat-to-Heat and/or Melt Practice Variation in Crack Growth Behavior of Inconel 718," in Report ORNL-5349, pp. 196-199, Oak Ridge National Laboratory, December 1977.

15. L. A. James, "Heat-to-Heat and/or Melt Practice Variations in Crack Growth Behavior of A1loy 718," in Report ORNL-5380, pp. 153-160, Oak Ridge National Laboratory, March 1978.

16. J. E. Srawley, "Wide Range Stress Intensity Factor Expressions for ASTM E399 Standard Fracture Toughness Specimens," International Journal of Fracture, Vol. 12, No. 3, pp. 475-476, 1976. 


\section{APPENDIX - NOMENCLATURE}

a, crack length

$B$, specimen thickness

C, specimen compliance

d, see Figure 1

$\mathrm{da} / \mathrm{dN}$, fatigue-crack growth rate

$D$, specimen diameter

E, Young's ModuTus

$f$, cyclic frequency

$G$, strain energy release rate

$K$, stress intensity factor

$L$, see Figure 1

$P$, applied load

$r$, radius of loading holes

$R$, stress ratio, $K_{\min } / K_{\max }$

$W$, specimen width

$Y$, dimensionless geometry factor, see Equation [8]

$a$, relative crack length, $a / W$

$\delta$, load-line displacement

$\Delta K$, stress intensity factor range, $K_{\max }-K_{\min }$ 
TABLE I

COMPARISON OF SPECIMEN GEOMETRIES

FOR ROUND COMPACT SPECIMENS

Specimen

Feddern \& Macherauch (Ref. 1)

Mowbray \& Andrews (Ref. 2)

Cull \& Starrett (Ref. 4)

Gross

(Ref. 6-8)

Underwood \& Kendall (Ref. 9)

Gregory
(Ref. 10)

Newman

Present Work (b)

Present Work (c)
$\frac{\mathrm{L}}{\mathrm{W}}$

0.333

0.333

0.333

0.333

0.333

1.333

0.266

0.133

$\frac{\text { Hole Location }}{\mathrm{d} / \mathrm{W}} \stackrel{r / w}{ }$

0.266

0.133

1.333

0.333

0.083

1.333

0.250

0.083

1.333
1.350

0.325

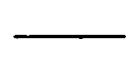

$0.275^{(a)}$

$0.125^{(a)}$

0.325

1.350

0.311

0.083

0.333

1.333

$0.275^{(a)}$

$0.125^{(a)}$

\footnotetext{
(a) Same as standard ASTM E647-78T Compact Specimen.

(b) Specimens 1519-1522.

(c) Specimen 1907 .
} 


\section{TABLE II}

CHEMICAL COMPOSITION OF ALLOY*

718 USED IN THIS STUDY

\begin{tabular}{cc} 
Element & Percent by Weight \\
\cline { 2 - 2 } $\mathrm{C}$ & 0.04 \\
$\mathrm{Mn}$ & 0.15 \\
$\mathrm{Fe}$ & 17.97 \\
$\mathrm{~S}$ & 0.005 \\
$\mathrm{Si}$ & 0.15 \\
$\mathrm{Cu}$ & 0.10 \\
$\mathrm{Ni}$ & 53.06 \\
$\mathrm{Cr}$ & 18.50 \\
$\mathrm{~A} 1$ & 0.62 \\
$\mathrm{Ti}$ & 0.95 \\
$\mathrm{Co}$ & 0.09 \\
$\mathrm{Mo}$ & 3.06 \\
$\mathrm{Cb} \& \mathrm{Ta}$ & 5.29 \\
&
\end{tabular}


TABLE III

SUMMARY OF TEST PARAMETERS

\begin{tabular}{|c|c|c|c|c|c|}
\hline $\begin{array}{l}\text { Specimen } \\
\text { Number }\end{array}$ & $\begin{array}{l}\text { Specimen } \\
\text { Type } \\
\end{array}$ & $\begin{array}{l}\text { Test } \\
\text { Temp. }\end{array}$ & $\begin{array}{l}\text { Maximum } \\
\text { Load } \\
\end{array}$ & $\begin{array}{l}\text { Range of } \\
\alpha \text { Tested } \\
\end{array}$ & $\begin{array}{l}\text { Cyclic } \\
\text { Frequency }\end{array}$ \\
\hline 1516 & Std. CS & $75^{\circ} \mathrm{F}$ & $900.7 \mathrm{~b}$. & $0.400<\alpha<0.806$ & $600 \mathrm{cpm}$ \\
\hline 1517 & Std. CS & $75^{\circ} \mathrm{F}$ & $13501 \mathrm{~b}$. & $0.405<\alpha<0.727$ & $600 \mathrm{cpm}$ \\
\hline 1518 & Std. cS & $1000^{\circ} \mathrm{F}$ & $10001 \mathrm{~b}$ & $0.415<\alpha<0.719$ & $40 \mathrm{cpm}$ \\
\hline 1579 & $\operatorname{RCS}$ & $75^{\circ} \mathrm{F}$ & $8001 \mathrm{lb}$ & $0.502<\alpha<0.847$ & $600 \mathrm{cpm}$ \\
\hline 1520 & RCS & $75^{\circ} \mathrm{F}$ & $12001 \mathrm{~b}$. & $0.508<\alpha<0.807$ & $600 \mathrm{cpm}$ \\
\hline 1521 & RCS & $1000^{\circ} \mathrm{F}$ & $8001 \mathrm{~b}$ & $0.493<\alpha<0.781$ & $40 \mathrm{cpm}$ \\
\hline 1522 & RCS & $1000^{\circ} \mathrm{F}$ & $12001 \mathrm{~b}$. & $0.497<\alpha<0.719$ & $40 \mathrm{cpm}$ \\
\hline 1907 & $\mathrm{RCS}$ & $75^{\circ} \mathrm{F}$ & $9501 \mathrm{~b}$. & $0.300<\alpha<0.782$ & $600 \mathrm{cpm}$ \\
\hline
\end{tabular}

All specimens tested at a stress ratio, $R=0.05$. 


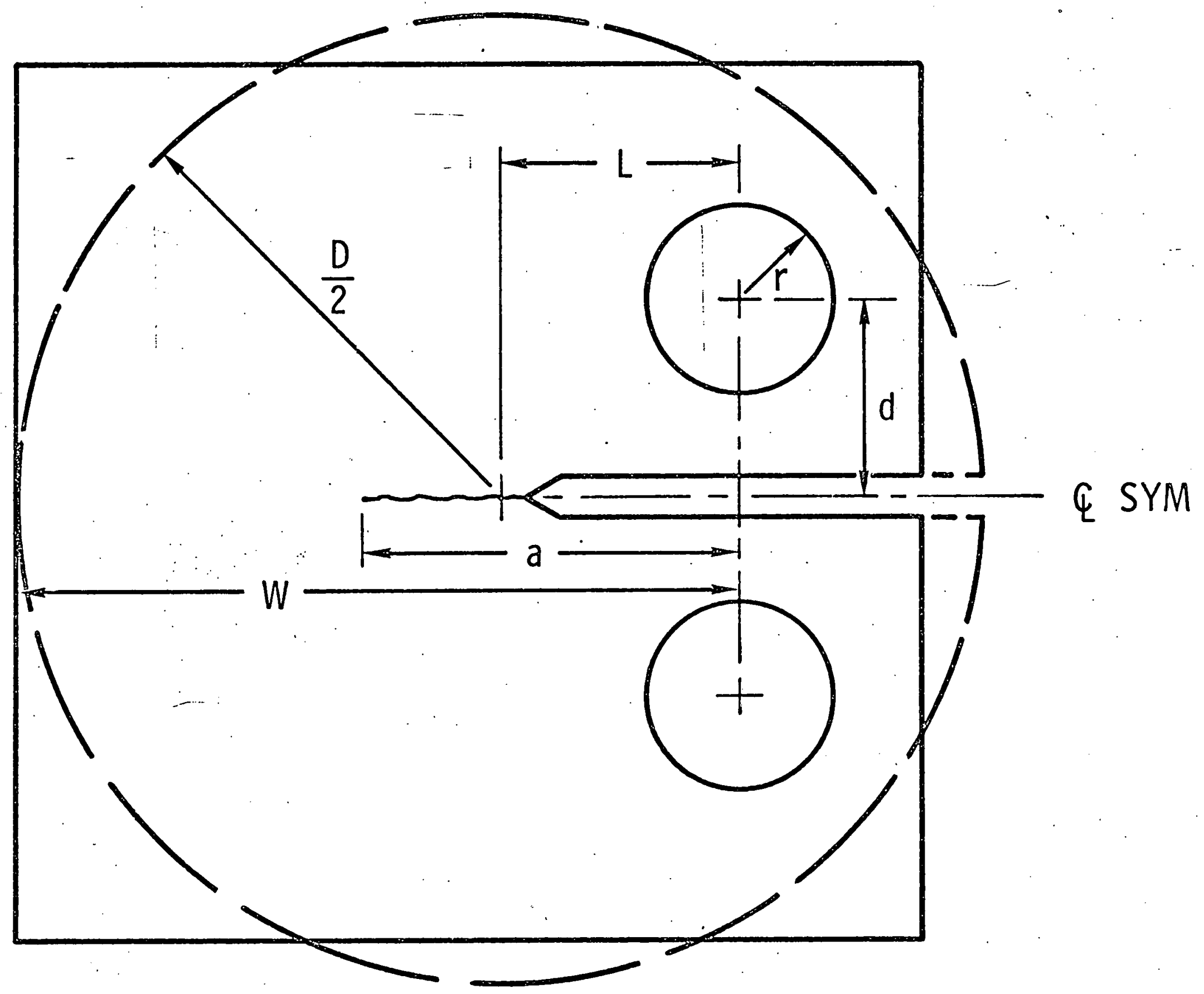

Figure $1: \cdots$ Standard Compact Specimen and proposed Round Compact Specimens. 


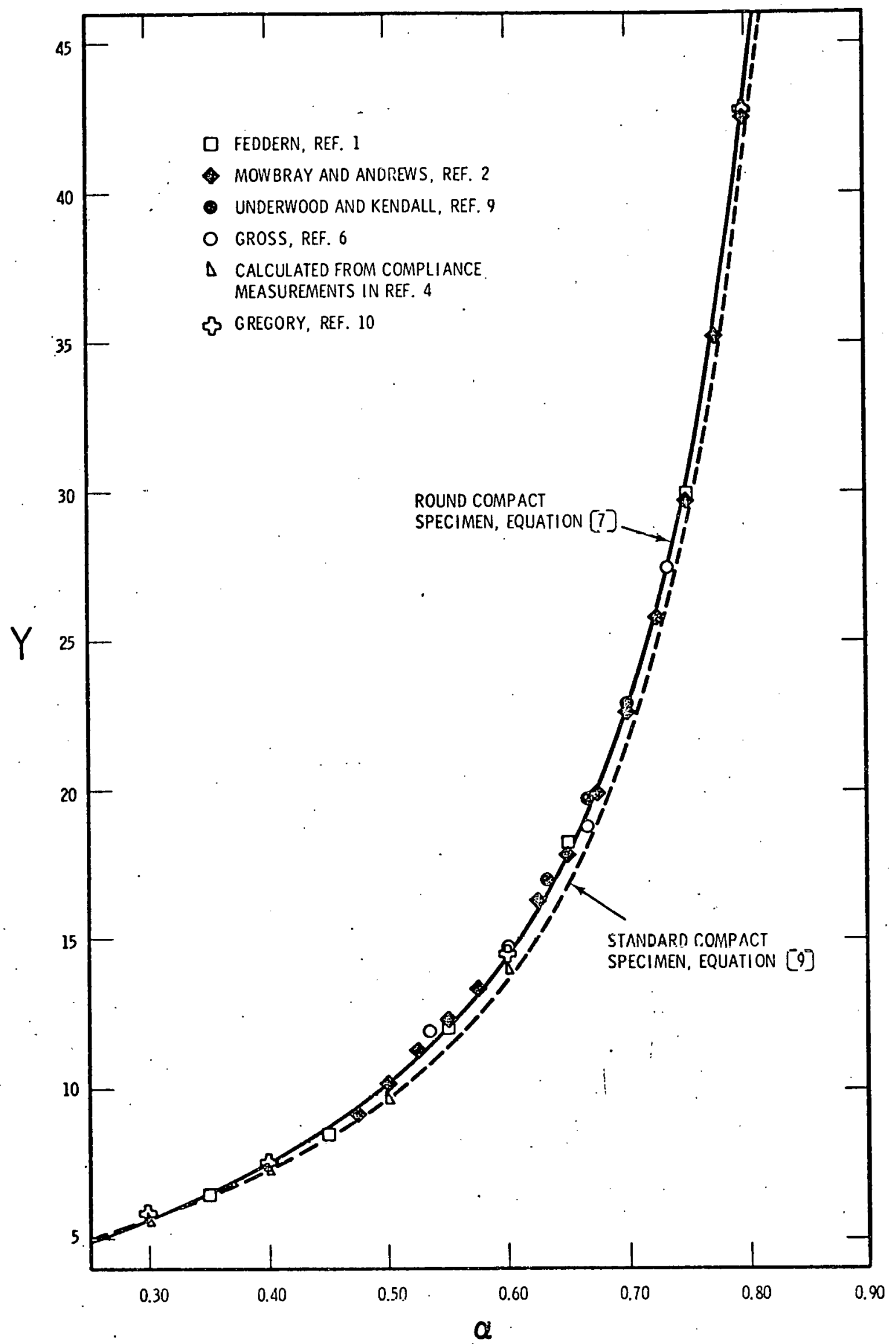

Figure 2. Comparison of results for various expressions for the Round Compect specimen. 


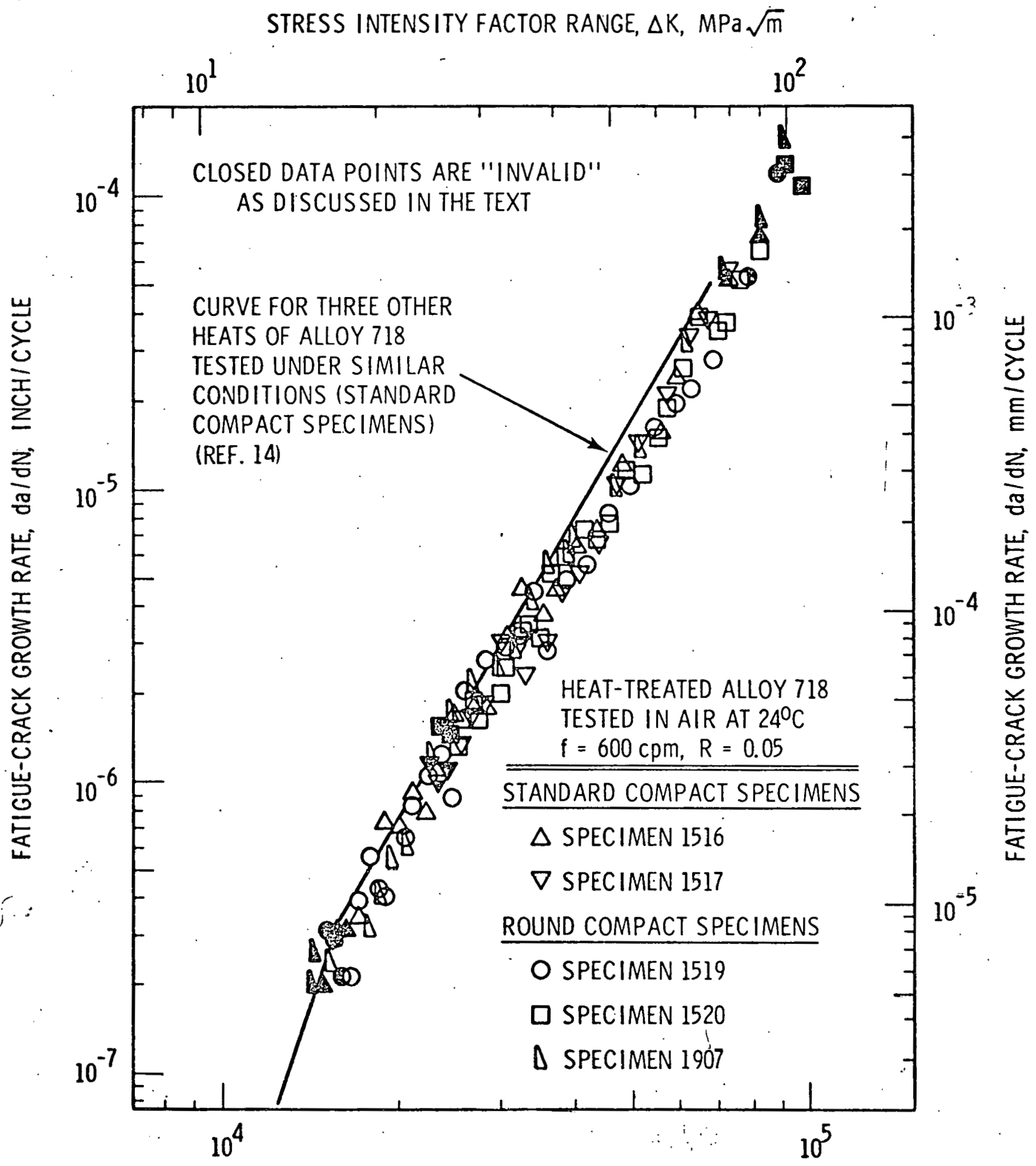

STRESS INTENSITY FACTOR RANGE, $\triangle K, p S i \sqrt{i n}$. 
STRESS INTENSITY FACTOR RANGE, $\triangle K, M P a \sqrt{m}$

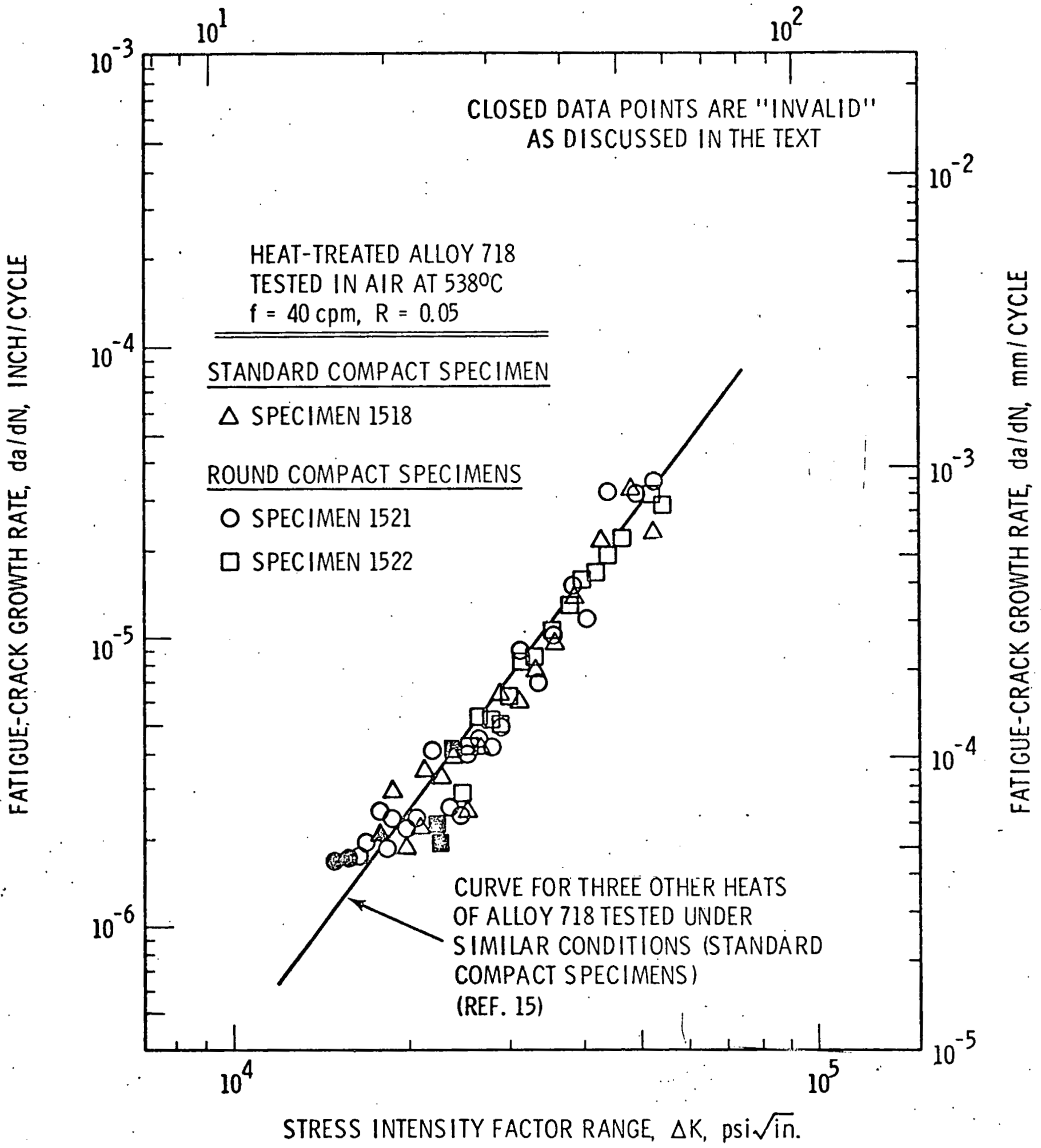

Figure 4. Comparison of results for Standard and Round Compact Specimens tested at $538^{\circ} \mathrm{C}\left(1000^{\circ} \mathrm{F}\right)$. 